\title{
28. MICROSTRUCTURE AND PHYSICAL PROPERTIES OF SAMPLES FROM HOLE 896A ${ }^{1}$
}

\author{
R.H. Wilkens ${ }^{2}$ and M.H. Salisbury ${ }^{3}$
}

\begin{abstract}
A set of 24 basaltic samples from Hole 896A was imaged using a backscatter electron detector on a scanning electron microscope. Laboratory compressional-wave velocities were measured at elevated confining pressure for 28 minicores from Hole $896 \mathrm{~A}$ core. Digital image analysis was used to distinguish total areas of plagioclase, olivine, and pyroxene as well as pores + alteration. Results of image processing qualitatively explain why samples with similar total porosity have markedly different compressional-wave velocity. Velocities and densities of Hole 896A samples were compared with laboratory results from the upper part of Hole 504B. Hole 896A samples tend to have lower velocities for a given bulk density than Hole 504B samples, probably a result of different pore structures of rocks from the two sites.
\end{abstract}

\section{INTRODUCTION}

Studies of the velocity structure of the oceanic crust have long formed a principal oceanic geophysical data set. The division of the crust into Layers 1, 2, and 3, as well as later subdivisions of Layer 2, were based entirely on remotely measured seismic velocities (Raitt, 1963; Christensen and Salisbury, 1975). This concept has formed the basis of our understanding of ocean crustal structure and, to the extent that velocity structure has been interpreted as geologic structure, has had great influence upon our thinking about crustal evolution and growth (e.g., Salisbury and Christensen, 1978). Recently there has been increased interest in the evolution of the seismic structure of the uppermost igneous crust (see Jacobson, 1992, for a review). It has been realized that much of the variation in the velocity structure of the ocean crust lies within the upper $500 \mathrm{~m}$ or so. Critical factors such as eruptive record, pore structure, and alteration history influence seismic velocity in the seafloor (Wilkens et al., 1991; Moos and Marion, 1994). In this study we examine laboratory velocity measurements of a set of basaltic samples from Ocean Drilling Program (ODP) Hole 896A. Variations in velocity-density-porosity systematics are discussed in the light of quantitative information from digital images of sample microstructure. Finally, we make qualitative observations about possible differences between these samples and others from nearby Hole 504B.

\section{SAMPLE DESCRIPTIONS AND EXPERIMENTAL TECHNIQUES}

During the course of ODP Leg 148, Hole 896A was drilled approximately $1 \mathrm{~km}$ southeast of the well-known Hole 504B (Fig. 1). Located on a local topographic high, Hole 896A is the locus of crustal pore-water upwelling (Mottl, 1989). It provides a contrast to neighboring Hole 504B, where ocean bottom water percolates through the sedimentary layer into the crust. Approximately $290 \mathrm{~m}$ of basement was drilled beneath $179 \mathrm{~m}$ of pelagic sediments. Most of the base-

'Alt, J.C., Kinoshita, H., Stokking, L.B., and Michael, P.J. (Eds.), 1996. Proc. ODP Sci. Results, 148: College Station, TX (Ocean Drilling Program).

${ }^{2}$ Hawaii Institute of Geophysics and Planetology, School of Ocean and Earth Science and Technology, University of Hawaii, 2525 Correa Road, Honolulu, HI 96822. U.S.A. wilkens@soest.hawaii.edu

${ }^{3}$ Geological Survey of Canada Atlantic, Bedford Institute of Oceanography, P.O. Box 1006, Dartmouth, Nova Scotia B2Y 4A2, Canada. matts@agc.bio.ns.ca ment section (95\%) consists of either pillow or massive basalts that are olivine and plagioclase \pm clinopyroxene phyric. Low-temperature alteration is present throughout the section, but not pervasive, with replacement of olivine by clay minerals the most common effect.

Twenty-eight samples were collected from the core for measurement of laboratory compressional-wave velocity. Velocities were measured to $600 \mathrm{MPa}$ confining pressure in 2.5-cm-diameter, rightcircular cylinders with an average length of approximately $2.0 \mathrm{~cm}$, using the pulse transmission technique (Birch, 1960). Velocities were recorded at room temperature using water-saturated samples. Wetbulk densities of the samples were measured and porosities calculated using grain densities from the same core pieces calculated aboard the JOIDES Resolution during Leg 148. Data are given in Table 1 and illustrated in Figure 2.

Image analysis of microstructure has been employed for at least two decades in the geological sciences (e.g., Hadley, 1976; Ehrlich, 1984; Berryman, 1985; Wilkens et al., 1984). Most of the work has had application in the oil industry-examination of pore systems in reservoirs, the role of clays in sandstone systems - but virtually nothing has been done with ocean crustal rocks. We think that image analysis is a powerful tool that will yield large dividends in future studies. Ehrlich et al. (1991) summarize the arguments well. Microfabric elements need quantitative analysis because the current system of thin section description is time consuming, requires years of training, and varies among individuals. Using digital image analysis techniques, quantification can be separated from classification. Data are repeatable results of well-defined techniques. Interpretations may change, but basic observations remain.

Eighteen of the velocity samples were among 24 core ends used for scanning electron microscope (SEM) examination of microstructure. Samples were polished to a flat surface and finished with 0.25 $\mu \mathrm{m}$ grit. Digital images (256 gray-scale levels) were recorded for three areas of each sample at three different magnifications $(100 \times$, $200 \times$, and $500 \times$ ) using a backscattered electron detector (Fig. 3). Backscattered electron intensity is directly proportional to the bulk density of the material under the electron beam (Caruso and Simmons, 1984; Pye and Krinsley, 1984). Dense objects appear bright whereas less dense material is increasingly gray. In our illustration (Fig. 3) we show three magnifications of a single spot on Sample $148-896 \mathrm{~A}-4 \mathrm{R}-1,51-53 \mathrm{~cm}$, as well as a histogram of gray-scale levels from the $500 \times$ image.

For image analysis we have chosen the NIH IMAGE program, available at no cost over the internet from the National Institutes of Health. IMAGE offers a range of analytical tools on a UNIX or MacIntosh system. Its cost (nothing) and ease of use assure that the results 


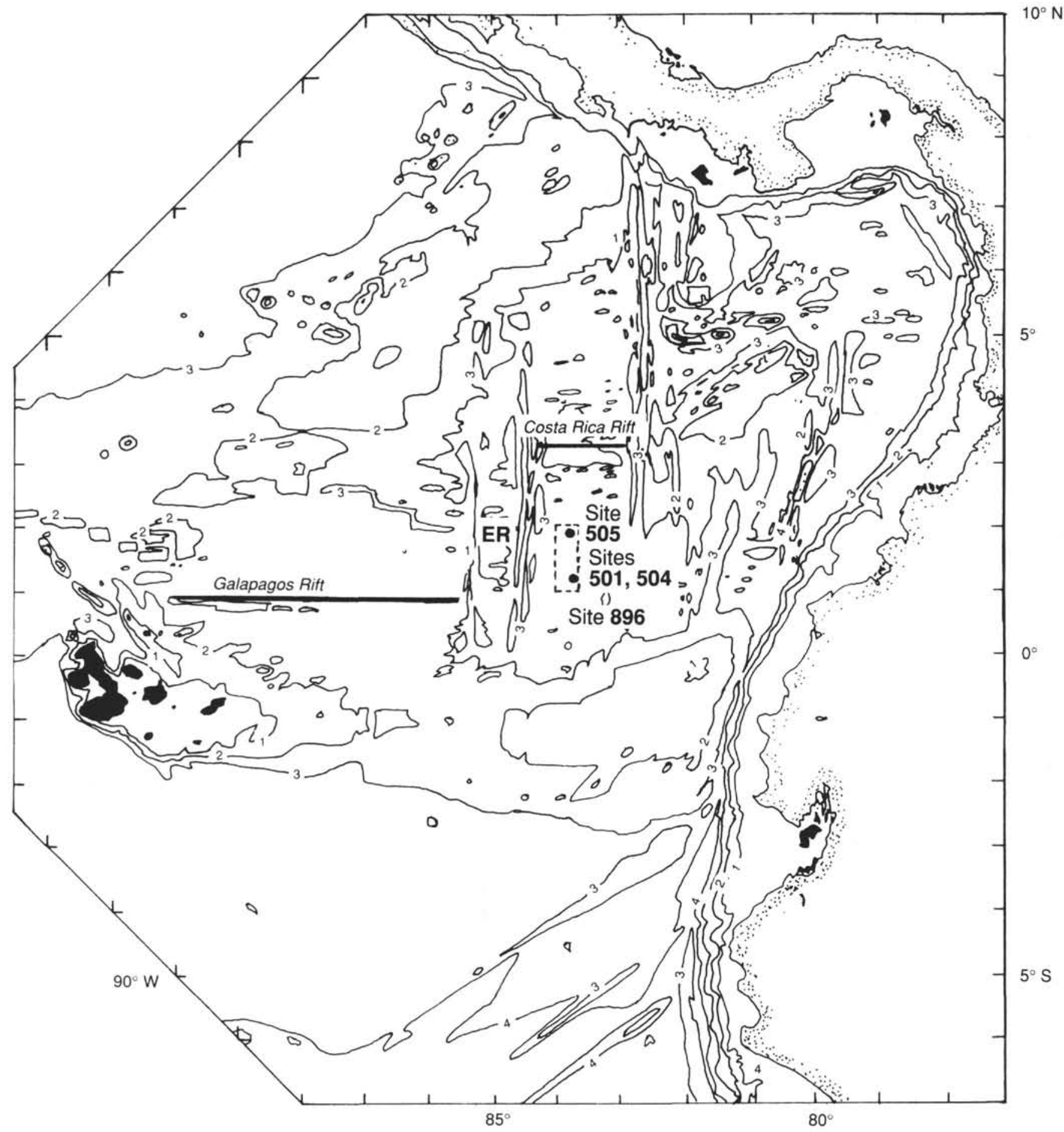

Figure 1. Location of DSDP Sites 501 and 505, DSDP/ODP Site 504, and ODP Site 896 south of the Costa Rica Rift in the eastern equatorial Pacific (after Hobart et al., 1985). Hole 896A is on a local high of about $30 \mathrm{~m}$.

we discuss below may be duplicated by any other researcher on his or her desktop.

The elements of Hole 896A sample images can be divided into three categories corresponding to light gray (olivine \pm clinopyroxene), medium gray (plagioclase), and dark gray to black (alteration material and pore space). An example of this tripartite separation is shown in Figure 4. Counts of the areas of each component are tabulated using histograms of gray-scale values for each image. Repeated use of this technique has shown that the areas of misidentification seen in the binary images are small $(1 \%-2 \%)$ compared to the natural variability within each sample. A summary of image data from 24 Hole 896A samples, with averages from three images at each magnification, is presented in Table 2.

\section{RESULTS}

Sample velocity at three different confining pressures and sample density are plotted vs. depth below seafloor in Figure 5. Density varies between 2.78 and $2.95 \mathrm{~g} / \mathrm{cm}^{3}$ whereas velocity ranges from 5.2 to 
Table 1. Wet bulk density, grain density, porosity, and compressional-wave velocity of samples from Hole 896A.

\begin{tabular}{|c|c|c|c|c|c|c|c|c|c|c|c|c|c|c|}
\hline \multirow[b]{2}{*}{$\begin{array}{l}\text { Core, section, } \\
\text { interval }(\mathrm{cm})\end{array}$} & \multirow[b]{2}{*}{$\begin{array}{l}\text { Depth } \\
\text { (mbsf) }\end{array}$} & \multirow[b]{2}{*}{ Lithology } & \multirow{2}{*}{$\begin{array}{c}\text { Wet bulk } \\
\text { density } \\
\left(\mathrm{g} / \mathrm{cm}^{3}\right)\end{array}$} & \multirow{2}{*}{$\begin{array}{c}\text { Grain } \\
\text { density } \\
\left(\mathrm{g} / \mathrm{cm}^{3}\right)\end{array}$} & \multirow[b]{2}{*}{ Porosity } & \multicolumn{9}{|c|}{$\begin{array}{c}V_{p}(\mathrm{~km} / \mathrm{s}) \\
\text { Pressure }(\mathrm{kb})\end{array}$} \\
\hline & & & & & & 0.1 & 0.2 & 0.4 & 0.6 & 0.8 & 1.0 & 2.0 & 4.0 & 6.0 \\
\hline \multicolumn{15}{|l|}{ 148-896A- } \\
\hline IR-1, 87-89 & 195.97 & Pillow basalt & 2.79 & 2.95 & 0.083 & 5.29 & 5.42 & 5.67 & 5.74 & 5.77 & 5.80 & 5.88 & 5.92 & 5.92 \\
\hline $2 \mathrm{R}-1,82-84$ & 201.72 & Pillow basalt & 2.83 & 2.97 & 0.072 & 5.11 & 5.32 & 5.57 & 5.65 & 5.70 & 5.75 & 5.92 & 6.04 & 6.06 \\
\hline $3 R-1,78-80$ & 210.68 & Pillow basalt & 2.84 & 2.96 & 0.062 & 5.23 & 5.31 & 5.46 & 5.62 & 5.74 & 5.76 & 5.82 & 5.87 & 5.89 \\
\hline $4 \mathrm{R}-\mathrm{I}, 44-46$ & 219.34 & Pillow basalt & 2.81 & 2.95 & 0.073 & 5.43 & 5.44 & 5.46 & 5.48 & 5.50 & 5.51 & 5.61 & 5.71 & 5.74 \\
\hline $4 \mathrm{R}-1,51-53$ & 219.41 & Pillow basalt. & 2.81 & 2.95 & 0.073 & 4.87 & 5.03 & 5.28 & 5.37 & 5.40 & 5.43 & 5.51 & 5.57 & 5.61 \\
\hline $5 R-3,43-45$ & 231.83 & Pillow basalt & 2.89 & 2.98 & 0.046 & 5.86 & 6.02 & 6.08 & 6.11 & 6.14 & 6.16 & 6.23 & 6.30 & 6.32 \\
\hline $6 R-2,3-5$ & 239.43 & Pillow rim & 2.95 & 3.00 & 0.025 & 6.06 & 6.21 & 6.31 & 6.38 & 6.43 & 6.47 & 6.54 & 6.58 & 6.60 \\
\hline $9 \mathrm{R}-2,4-6$ & 268.24 & Pillow basalt & 2.85 & 2.93 & 0.042 & 5.79 & 6.02 & 6.12 & 6.15 & 6.16 & 6.17 & 6.21 & 6.25 & 6.29 \\
\hline $11 \mathrm{R}-1,32-34$ & 286.32 & Pillow basalt & 2.84 & 2.93 & 0.047 & 5.96 & 6.04 & 6.15 & 6.22 & 6.27 & 6.31 & 6.44 & 6.48 & 6.51 \\
\hline $17 \mathrm{R}-2,126-128$ & 346.26 & Pillow basalt & 2.87 & 2.97 & 0.051 & 5.73 & 5.78 & 5.87 & 5.96 & 6.05 & 6.14 & 6.31 & 6.42 & 6.49 \\
\hline $17 \mathrm{R}-2,129-131$ & 346.29 & Pillow basalt & 2.89 & 2.97 & 0.041 & 5.66 & 5.73 & 5.81 & 5.85 & 5.88 & 5.90 & 5.97 & 6.04 & 6.08 \\
\hline $17 \mathrm{R}-3,37-39$ & 346.87 & Pillow basalt & 2.85 & 2.95 & 0.052 & 5.47 & 5.65 & 5.73 & 5.78 & 5.82 & 5.84 & 5.91 & 5.96 & 5.97 \\
\hline $18 \mathrm{R}-1,102-104$ & 354.12 & Pillow basalt & 2.88 & 2.96 & 0.041 & 5.37 & 5.42 & 5.51 & 5.57 & 5.63 & 5.68 & 5.85 & 6.00 & 6.09 \\
\hline $20 \mathrm{R}-1,63-65$ & 364.13 & Pillow basalt & 2.83 & 2.97 & 0.072 & 5.58 & 5.64 & 5.72 & 5.78 & 5.82 & 5.85 & 5.91 & 5.95 & 5.97 \\
\hline $20 \mathrm{R}-1,101-103$ & 364.51 & Pillow basalt & 2.84 & 2.97 & 0.067 & 5.36 & 5.46 & 5.58 & 5.64 & 5.67 & 5.70 & $5.7 i$ & 5.86 & 5.93 \\
\hline $21 \mathrm{R}-2,85-87$ & 375.35 & Massive basalt & 2.8 & 2.96 & 0.083 & 5.03 & 5.10 & 5.21 & 5.32 & 5.39 & 5.44 & 5.57 & 5.74 & 5.79 \\
\hline $22 \mathrm{R}-3,26-28$ & 385.86 & Massive basalt & 2.86 & 2.99 & 0.066 & 5.64 & 5.86 & 5.92 & 5.96 & 5.99 & 6.01 & 6.09 & 6.16 & 6.18 \\
\hline $23 \mathrm{R}-1,77-79$ & 392.87 & Basalt & 2.78 & 2.95 & 0.088 & & 5.29 & 5.34 & 5.38 & 5.43 & 5.47 & 5.68 & 5.81 & 5.83 \\
\hline $23 \mathrm{R}-3,6-8$ & 395.16 & Massive basalt & 2.82 & 2.94 & 0.063 & 4.29 & 4.85 & 4.95 & 5.04 & 5.14 & 5.22 & 5.51 & 5.74 & 5.81 \\
\hline $24 \mathrm{R}-1,125-127$ & 401.925 & Massive basalt & 2.95 & 2.97 & 0.010 & & 6.06 & 6.22 & 6.28 & 6.32 & 6.36 & 6.48 & 6.59 & 6.62 \\
\hline $25 \mathrm{R}-3,52-54$ & 414.82 & Basalt & 2.89 & 2.95 & 0.031 & 5.60 & 5.79 & 5.96 & 6.00 & 6.04 & 6.07 & 6.22 & 6.49 & 6.58 \\
\hline $26 \mathrm{R}-1,63-65$ & 421.63 & Basalt & 2.86 & 2.93 & 0.037 & 5.56 & 5.58 & 5.62 & 5.64 & 5.67 & 5.69 & 5.73 & 5.75 & 5.78 \\
\hline $26 \mathrm{R}-2,27-29$ & 422.77 & Basalt & 2.83 & 2.91 & 0.042 & 5.61 & 5.69 & 5.74 & 5.78 & 5.80 & 5.82 & 5.88 & 5.92 & 5.94 \\
\hline $27 \mathrm{R}-1,69-71$ & 431.19 & Basalt & 2.81 & 2.95 & 0.073 & 5.02 & 5.33 & 5.48 & 5.56 & 5.61 & 5.66 & 5.73 & 5.81 & 5.85 \\
\hline $28 \mathrm{R}-2,15-17$ & 441.65 & Basalt & 2.84 & 2.94 & 0.052 & 5.39 & 5.42 & 5.49 & 5.55 & 5.62 & 5.68 & 5.87 & 5.98 & 6.03 \\
\hline $28 \mathrm{R}-2,39-4 \mathrm{I}$ & 441.89 & Basalt & 2.91 & 3.00 & 0.046 & & & & & 6.01 & 6.06 & 6.16 & 6.20 & 6.22 \\
\hline $29 \mathrm{R}-1,93-95$ & 450.63 & Basalt & 2.81 & 2.98 & 0.087 & 5.27 & 5.33 & 5.44 & 5.56 & 5.67 & 5.74 & 5.85 & 5.93 & 6.01 \\
\hline $30 \mathrm{R}-1,36-38$ & 459.66 & Basalt & 2.95 & 3.01 & 0.030 & 5.83 & 5.99 & 6.10 & 6.18 & 6.24 & 6.26 & 6.30 & 6.33 & 6.35 \\
\hline
\end{tabular}

Note: $V_{p}=$ compressional-wave velocity.

$6.5 \mathrm{~km} / \mathrm{s}$ at $100 \mathrm{MPa}$. The uniformity of velocity increase seen with pressure increase for each sample over the depth range emphasizes the similarity in the velocity-pressure plots shown in Figure 2. Logging velocity recorded over the interval from 215 to $400 \mathrm{~m}$ below seafloor (mbsf) varies between 4.0 and $5.0 \mathrm{~km} / \mathrm{s}$-roughly $1 \mathrm{~km} / \mathrm{s}$ slower than the laboratory samples. This discrepancy has been seen many times in pillow basalt sections, and has been attributed to the scale of fractures and other structures larger than the laboratory minicores (Salisbury et al., 1985; Wilkens et al., 1988; and many others).

Compressional-wave velocity at $100 \mathrm{MPa}$ is plotted vs. wet-bulk density in Figure 6. The curve is a nonlinear best fit for 77 seafloor basalts given in Christensen and Salisbury (1975). Also included are laboratory results from the upper $350 \mathrm{~m}$ of crust at Hole 504B (Wilkens et al., 1983). Hole 896A samples tend to have lower densities than those from Hole 504B, mainly the result of somewhat lower porosities at Hole 504B (Fig. 7), because grain densities are generally the same. In addition, there appears to be a tendency for the Hole 896 A samples to have a lower velocity at a given density than the Hole 504B samples.

The nature of the pore space within the Hole 896A sample set provides some clues to the difference in behavior between Hole 896A and Hole 504B. We have labeled the locations of samples run in the laboratory and imaged using the SEM in Figure 7. Also shown are Hole 504B laboratory results. Note that the Hole 896A samples have generally higher porosities for velocities similar to those of the Hole 504B samples. Representative images of Samples 148-896A-26R-1, 64-66 cm, and 148-896A-1R-1, 84-86 cm, are shown in Figures 8 and 9 . Both samples have velocities of about $5.8 \mathrm{~km} / \mathrm{s}$, yet the sample from Core $26 \mathrm{R}$ has a porosity slightly less than $4 \%$ whereas the sample from Core $1 \mathrm{R}$ has a porosity near $8 \%$. At first glance the textures of the two samples appear similar. Closer observation, however, suggests that the major difference between the two samples is that the pore space in the Core $1 \mathrm{R}$ sample is open-clear of alteration products-whereas pores in the sample from Core 26R are filled with clays. Interestingly, image analysis of the two samples (Table 2)

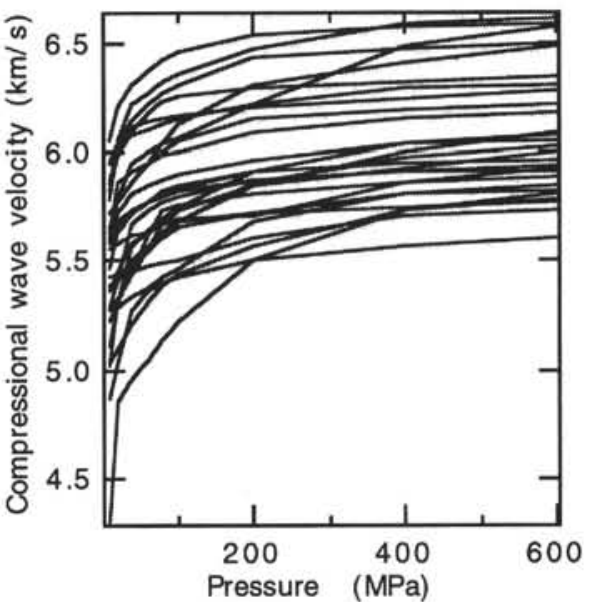

Figure 2. Velocity vs. confining pressure for Hole $896 \mathrm{~A}$ samples. The 10 $\mathrm{MPa}$ velocities are mostly between 5.0 and $6.0 \mathrm{~km} / \mathrm{s}$ whereas $600 \mathrm{MPa}$ val ues are between 5.6 and $6.6 \mathrm{~km} / \mathrm{s}$.

shows that each have similar abundances (approximately 20\% seen at $100 \times$ ) of pore + alteration material. A similar contrast exists between Samples 148-896A-25R-3, 52-54 cm (Fig. 10) and 148-896A-22R$3,26-28 \mathrm{~cm}$ (Fig. 11). Indeed, many of the samples with relatively "high" porosity values (for a given velocity) have clean pores (Fig. 12; Sample 148-896A-30R-1, 34-36 cm, as another example) whereas "low" porosity samples (see again Sample 148-896A-4R-1, 51-53 $\mathrm{cm}$; Fig. 3) have a much greater proportion of pore-filling material.

Not all samples, unfortunately, obey this simple pattern. Several are relatively completely altered, as in Sample 148-896A-29R-1, 92$94 \mathrm{~cm}$ (Fig. 13). This sample has properties similar to Sample 148$896 \mathrm{~A}-1 \mathrm{R}-1,84-86 \mathrm{~cm}$ (Fig. 7), but has a markedly different microstructure (Fig. 9). Previous examples have consisted of rocks com- 

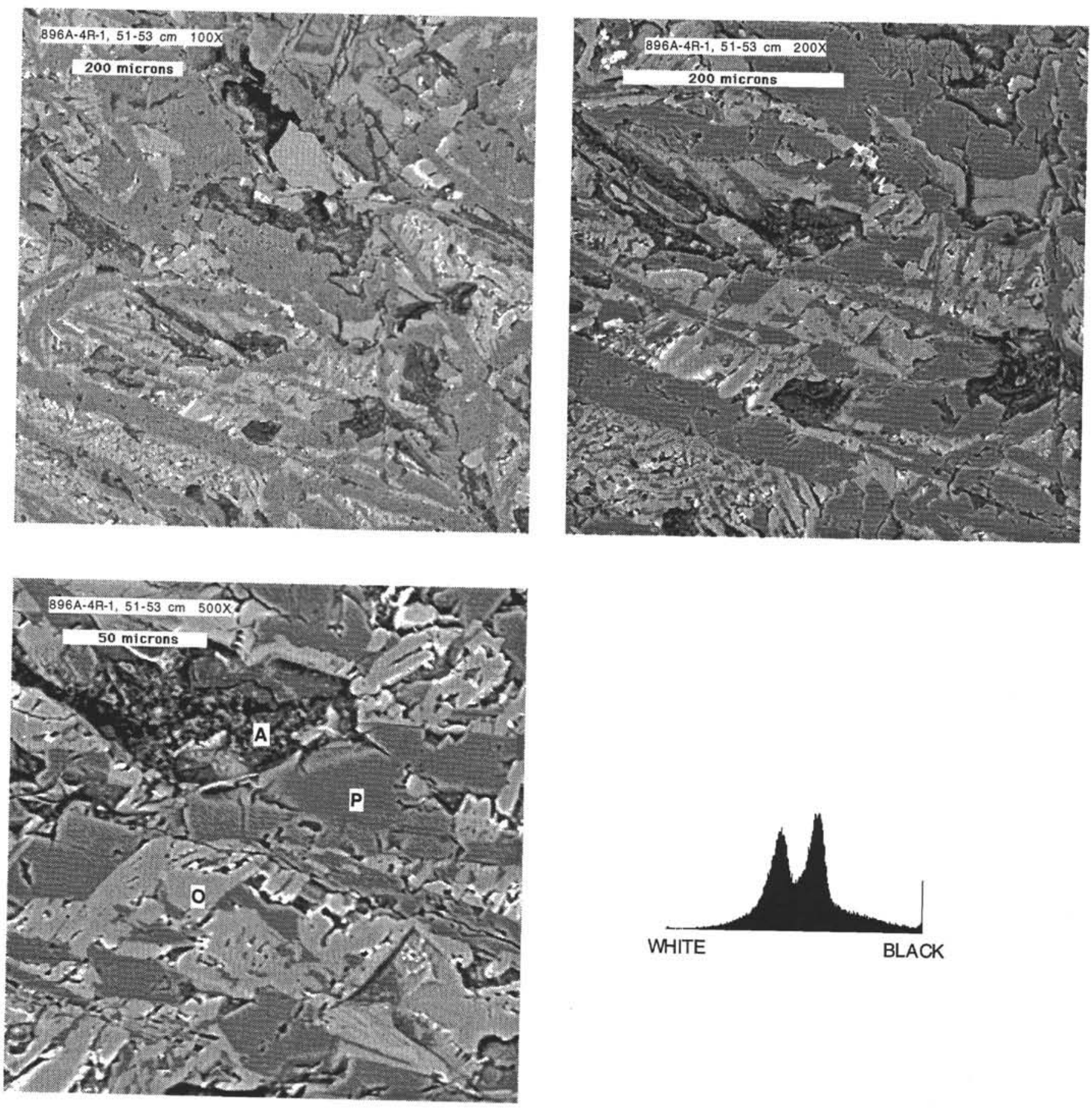

Figure 3. Digital images of a single sample at three magnifications. Images made with a backscattered electron detector on a scanning electron microscope. Also shown is a histogram of gray-scale levels from the $500 \times$ image. $\mathrm{A}=$ alteration phase, $\mathrm{P}=$ plagioclase, and $\mathrm{O}=$ olivine.

posed of plagioclase and olivine \pm alteration in pore spaces. The microstructure of these materials is made up of unaltered igneous grains. Velocities reflect a framework of fresh grains, pores, and cracks (either open or filled). Sample 148-896A-29R-1, 92-94 cm, has a framework composed of altered grains, and thus cannot be directly compared to most other samples.

Total alteration area + pore space is plotted vs. depth in Figure 14. Areas seem to decrease from the near the top of the crust and then to increase toward bottom (unfortunately, we could use a few more samples between 300 and $350 \mathrm{mbsf}$ ). Several samples are off-scale at the bottom because of pervasive alteration. The trend in alteration area mimics somewhat trends in velocity in Figure 5 (high velocitysmaller alteration area), but the correspondence is no stronger than that of porosity alone. In fact, we had hoped through this analysis to produce better velocity-porosity systematics, but have been left with only qualitative observations.

\section{DISCUSSION}

Comparison of Hole 896A data with Hole 504B data reinforces a feeling that samples from different locations often behave differently. 


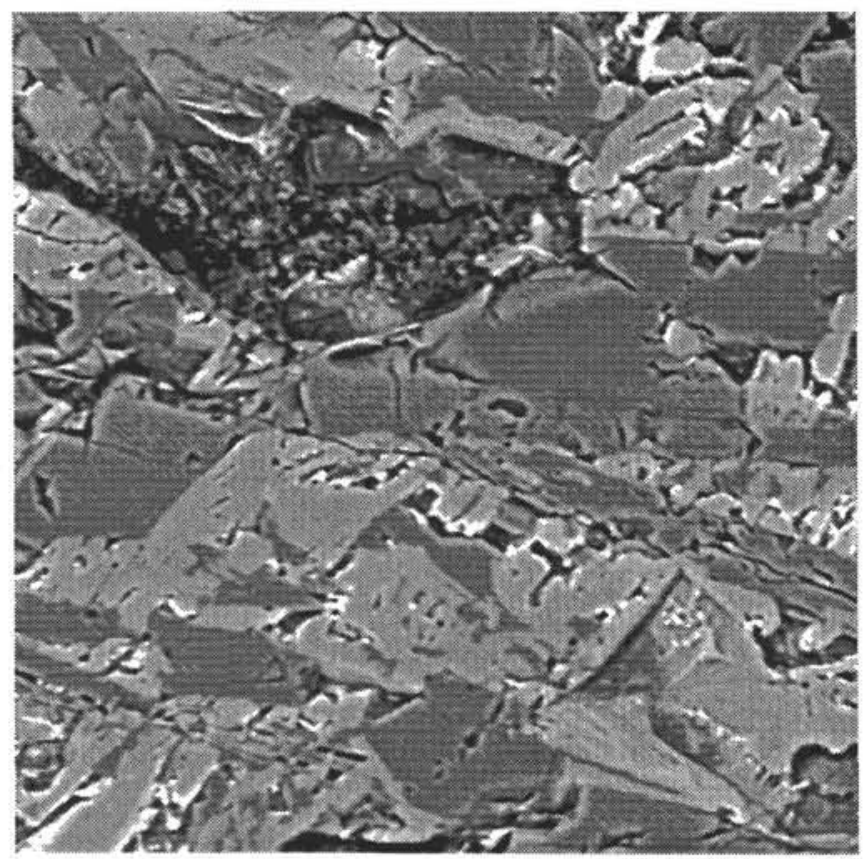

$896 \mathrm{~A}-4 \mathrm{R}-1,51-53 \mathrm{~cm} \quad 500 \mathrm{X}$

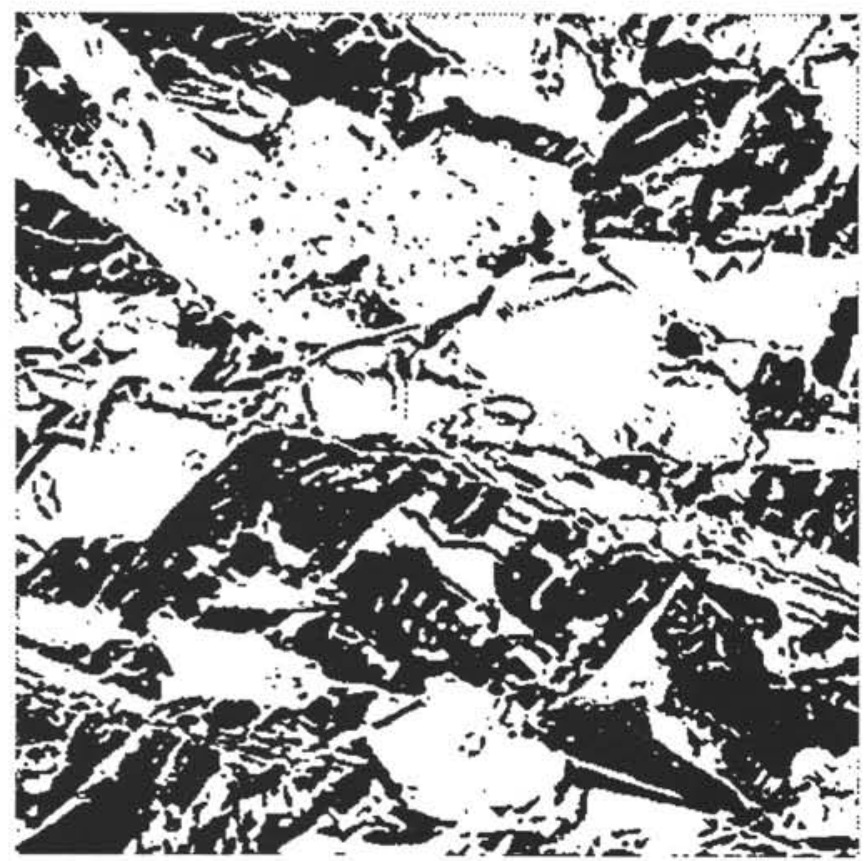

$41 \%$

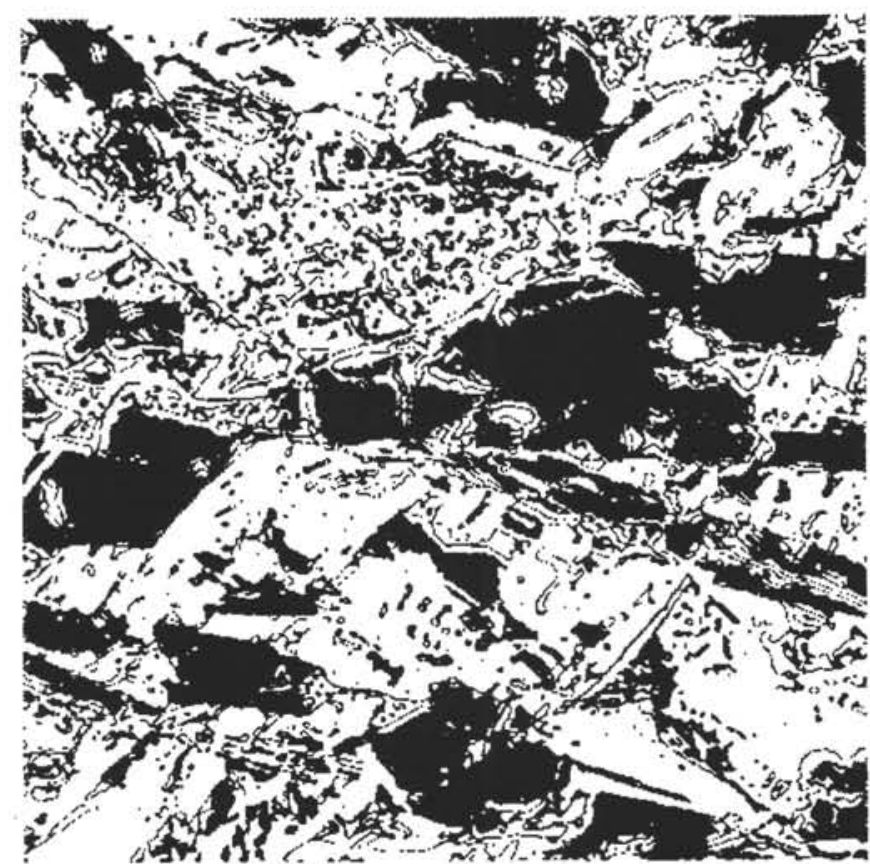

$43 \%$

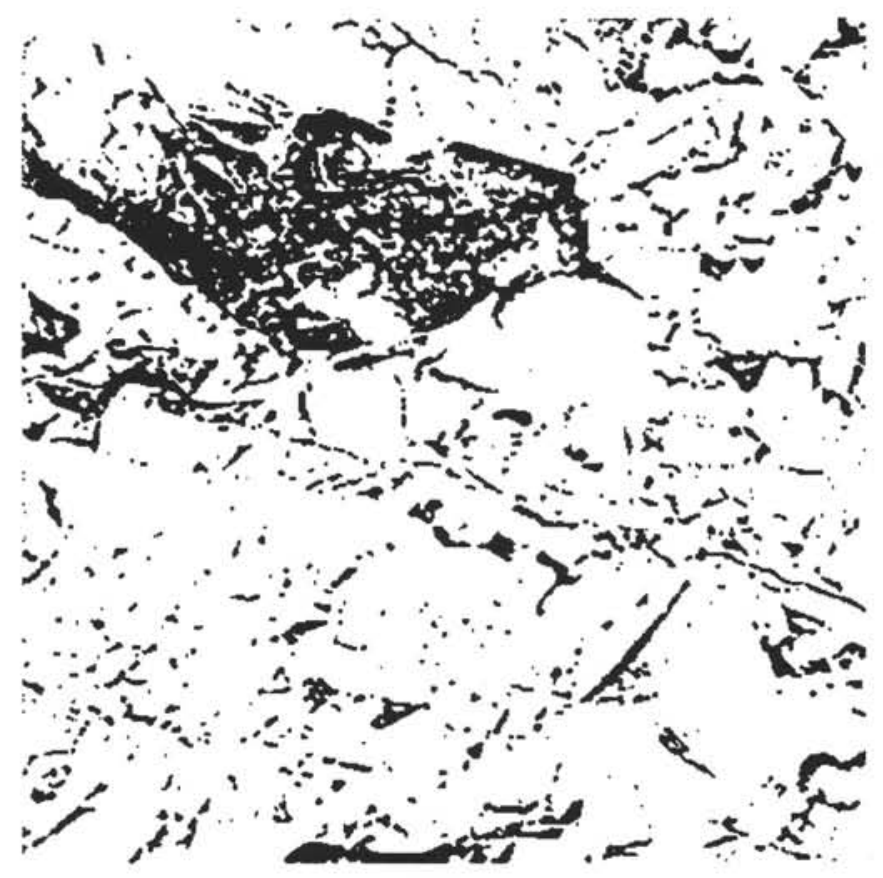

$16 \%$

Figure 4. Breakdown of 500X image into three components using histogram from Figure 3. Upper right is mostly plagioclase, lower left is olivine, and lower right is pore space and alteration phase. Areas calculated from the histogram are noted under each binary image.

In this case it is probably the result of differing alteration states. Relatively low porosities of Hole 504B samples, if they were much the same as those of Hole 896A, would suggest alteration-filled pores. However, given the fact that Site 504 has not been subjected to longterm upwelling of warm crustal pore water, it is unlikely that this is the case. Instead, Hole 504B samples (which we have yet to examine) may not have large areas of alteration. Intact, rather than altered, olivines will lower porosity in a sample while not markedly raising ve- locity because the pores or alteration areas are roughly spheroidal and do not contribute to velocity decrease in the same manner as cracks.

\section{CONCLUSION}

This is the first application, for us, of image analysis techniques to problems involving the systematics of laboratory data from igne- 
Table 2. Average distributions of image elements.

\begin{tabular}{|c|c|c|c|c|}
\hline $\begin{array}{l}\text { Core, section, } \\
\text { interval }(\mathrm{cm})\end{array}$ & Magnification & $\begin{array}{l}\text { Light } \\
\text { gray }\end{array}$ & $\begin{array}{l}\text { Dark } \\
\text { gray }\end{array}$ & $\begin{array}{l}\text { Alteration } \\
\text { and black }\end{array}$ \\
\hline $\begin{array}{l}\text { 148-896A- } \\
\text { IR-1.84-86 }\end{array}$ & $\begin{array}{l}100 x \\
200 x \\
500 x\end{array}$ & $\begin{array}{l}0.28 \\
0.42 \\
0.37\end{array}$ & $\begin{array}{l}0.52 \\
0.36 \\
0.37\end{array}$ & $\begin{array}{l}0.20 \\
0.22 \\
0.26\end{array}$ \\
\hline $4 \mathrm{R}-1,51-53$ & $\begin{array}{l}100 x \\
200 x \\
500 x\end{array}$ & $\begin{array}{l}0.32 \\
0.36 \\
0.38\end{array}$ & $\begin{array}{l}0.52 \\
0.49 \\
0.43\end{array}$ & $\begin{array}{l}0.16 \\
0.15 \\
0.19\end{array}$ \\
\hline $5 R-3,39-41$ & $\begin{array}{l}100 x \\
200 x \\
500 x\end{array}$ & $\begin{array}{l}0.43 \\
0.46 \\
0.51\end{array}$ & $\begin{array}{l}0.47 \\
0.38 \\
0.27\end{array}$ & $\begin{array}{l}0.10 \\
0.16 \\
0.22\end{array}$ \\
\hline $9 R-2,2-4$ & $\begin{array}{l}100 x \\
200 x \\
500 x\end{array}$ & $\begin{array}{l}0.72 \\
0.82 \\
0.70\end{array}$ & $\begin{array}{l}0.22 \\
0.15 \\
0.23\end{array}$ & $\begin{array}{l}0.06 \\
0.03 \\
0.07\end{array}$ \\
\hline $16 \mathrm{R}-1,26-28$ & $\begin{array}{l}100 x \\
200 x \\
500 x\end{array}$ & $\begin{array}{l}0.41 \\
0.40 \\
0.38\end{array}$ & $\begin{array}{l}0.48 \\
0.44 \\
0.38\end{array}$ & $\begin{array}{l}0.11 \\
0.16 \\
0.25\end{array}$ \\
\hline $16 \mathrm{R}-2,127-129$ & $\begin{array}{l}100 x \\
200 x \\
500 x\end{array}$ & $\begin{array}{l}0.32 \\
0.36 \\
0.46\end{array}$ & $\begin{array}{l}0.52 \\
0.47 \\
0.34\end{array}$ & $\begin{array}{l}0.16 \\
0.17 \\
0.20\end{array}$ \\
\hline $17 R-2,126-128$ & $\begin{array}{l}100 x \\
200 x \\
500 x\end{array}$ & $\begin{array}{l}0.26 \\
0.34 \\
0.39\end{array}$ & $\begin{array}{l}0.61 \\
0.50 \\
0.45\end{array}$ & $\begin{array}{l}0.12 \\
0.16 \\
0.16\end{array}$ \\
\hline $18 \mathrm{R}-1,102-104$ & $\begin{array}{l}100 x \\
200 x \\
500 x\end{array}$ & $\begin{array}{l}0.32 \\
0.33 \\
0.41\end{array}$ & $\begin{array}{l}0.58 \\
0.51 \\
0.40\end{array}$ & $\begin{array}{l}0.10 \\
0.15 \\
0.20\end{array}$ \\
\hline $19 \mathrm{R}-2,41-43$ & $\begin{array}{l}100 x \\
200 x \\
500 x\end{array}$ & $\begin{array}{l}0.50 \\
0.46 \\
0.49\end{array}$ & $\begin{array}{l}0.45 \\
0.47 \\
0.43\end{array}$ & $\begin{array}{l}0.05 \\
0.06 \\
0.09\end{array}$ \\
\hline $21 \mathrm{R}-1,57-59$ & $\begin{array}{l}100 x \\
200 x \\
500 x\end{array}$ & $\begin{array}{l}0.26 \\
0.27 \\
0.35\end{array}$ & $\begin{array}{l}0.62 \\
0.57 \\
0.51\end{array}$ & $\begin{array}{l}0.12 \\
0.16 \\
0.14\end{array}$ \\
\hline $21 \mathrm{R}-2,140-142$ & $\begin{array}{l}100 x \\
200 x \\
500 x\end{array}$ & $\begin{array}{l}0.42 \\
0.37 \\
0.38\end{array}$ & $\begin{array}{l}0.47 \\
0.33 \\
0.37\end{array}$ & $\begin{array}{l}0.11 \\
0.19 \\
0.25\end{array}$ \\
\hline $22 \mathrm{R}-1,107-109$ & $\begin{array}{l}100 x \\
200 x \\
500 x\end{array}$ & $\begin{array}{l}0.39 \\
0.32 \\
0.30\end{array}$ & $\begin{array}{l}0.40 \\
0.36 \\
0.31\end{array}$ & $\begin{array}{l}0.21 \\
0.32 \\
0.39\end{array}$ \\
\hline $22 \mathrm{R}-3,26-28$ & $\begin{array}{l}100 x \\
200 x \\
500 x\end{array}$ & $\begin{array}{l}0.35 \\
0.39 \\
0.47\end{array}$ & $\begin{array}{l}0.45 \\
0.44 \\
0.34\end{array}$ & $\begin{array}{l}0.20 \\
0.17 \\
0.19\end{array}$ \\
\hline $23 R-1,12-14$ & $\begin{array}{l}100 x \\
200 x \\
500 x\end{array}$ & $\begin{array}{l}0.46 \\
0.54 \\
0.49\end{array}$ & $\begin{array}{l}0.31 \\
0.31 \\
0.42\end{array}$ & $\begin{array}{l}0.23 \\
0.15 \\
0.09\end{array}$ \\
\hline $23 \mathrm{R}-1,78-80$ & $\begin{array}{l}100 x \\
200 x \\
500 x\end{array}$ & $\begin{array}{l}0.27 \\
0.27 \\
0.30\end{array}$ & $\begin{array}{l}0.60 \\
0.54 \\
0.55\end{array}$ & $\begin{array}{l}0.13 \\
0.18 \\
0.14\end{array}$ \\
\hline $24 \mathrm{R}-3,139-141$ & $\begin{array}{l}100 x \\
200 x \\
500 x\end{array}$ & $\begin{array}{l}0.28 \\
0.30 \\
0.32\end{array}$ & $\begin{array}{l}0.53 \\
0.49 \\
0.40\end{array}$ & $\begin{array}{l}0.19 \\
0.21 \\
0.28\end{array}$ \\
\hline $25 \mathrm{R}-1,49-51$ & $\begin{array}{l}100 x \\
200 x \\
500 x\end{array}$ & $\begin{array}{l}0.27 \\
0.25 \\
0.23\end{array}$ & $\begin{array}{l}0.62 \\
0.62 \\
0.59\end{array}$ & $\begin{array}{l}0.11 \\
0.13 \\
0.19\end{array}$ \\
\hline $25 \mathrm{R}-3,52-54$ & $\begin{array}{l}100 x \\
200 x \\
500 x\end{array}$ & $\begin{array}{l}0.23 \\
0.23 \\
0.29\end{array}$ & $\begin{array}{l}0.62 \\
0.58 \\
0.53\end{array}$ & $\begin{array}{l}0.16 \\
0.19 \\
0.17\end{array}$ \\
\hline $26 \mathrm{R}-1,64-66$ & $\begin{array}{l}100 x \\
200 x \\
500 x\end{array}$ & $\begin{array}{l}0.21 \\
0.24 \\
0.31\end{array}$ & $\begin{array}{l}0.60 \\
0.52 \\
0.46\end{array}$ & $\begin{array}{l}0.19 \\
0.24 \\
0.23\end{array}$ \\
\hline 26R-2, 27-29 & $\begin{array}{l}100 x \\
200 x \\
500 x\end{array}$ & $\begin{array}{l}0.26 \\
0.29 \\
0.36\end{array}$ & $\begin{array}{l}0.60 \\
0.53 \\
0.43\end{array}$ & $\begin{array}{l}0.14 \\
0.17 \\
0.21\end{array}$ \\
\hline $28 \mathrm{R}-2,12-14$ & $\begin{array}{l}100 x \\
200 x \\
500 x\end{array}$ & $\begin{array}{l}0.00 \\
0.00 \\
0.00\end{array}$ & $\begin{array}{l}0.16 \\
0.21 \\
0.23\end{array}$ & $\begin{array}{l}0.84 \\
0.80 \\
0.77\end{array}$ \\
\hline $28 \mathrm{R}-2,38-40$ & $\begin{array}{l}100 x \\
200 x \\
500 x\end{array}$ & $\begin{array}{l}0.44 \\
0.49 \\
0.50\end{array}$ & $\begin{array}{l}0.37 \\
0.29 \\
0.23\end{array}$ & $\begin{array}{l}0.19 \\
0.22 \\
0.27\end{array}$ \\
\hline $29 \mathrm{R}-1,92-94$ & $\begin{array}{l}100 x \\
200 x \\
500 x\end{array}$ & $\begin{array}{l}0.10 \\
0.10 \\
0.16\end{array}$ & $\begin{array}{l}0.29 \\
0.30 \\
0.24\end{array}$ & $\begin{array}{l}0.62 \\
0.60 \\
0.60\end{array}$ \\
\hline $30 \mathrm{R}-1,34-36$ & $\begin{array}{l}100 x \\
200 x \\
500 x\end{array}$ & $\begin{array}{l}0.36 \\
0.39 \\
0.39\end{array}$ & $\begin{array}{l}0.41 \\
0.35 \\
0.33\end{array}$ & $\begin{array}{l}0.23 \\
0.26 \\
0.27\end{array}$ \\
\hline
\end{tabular}

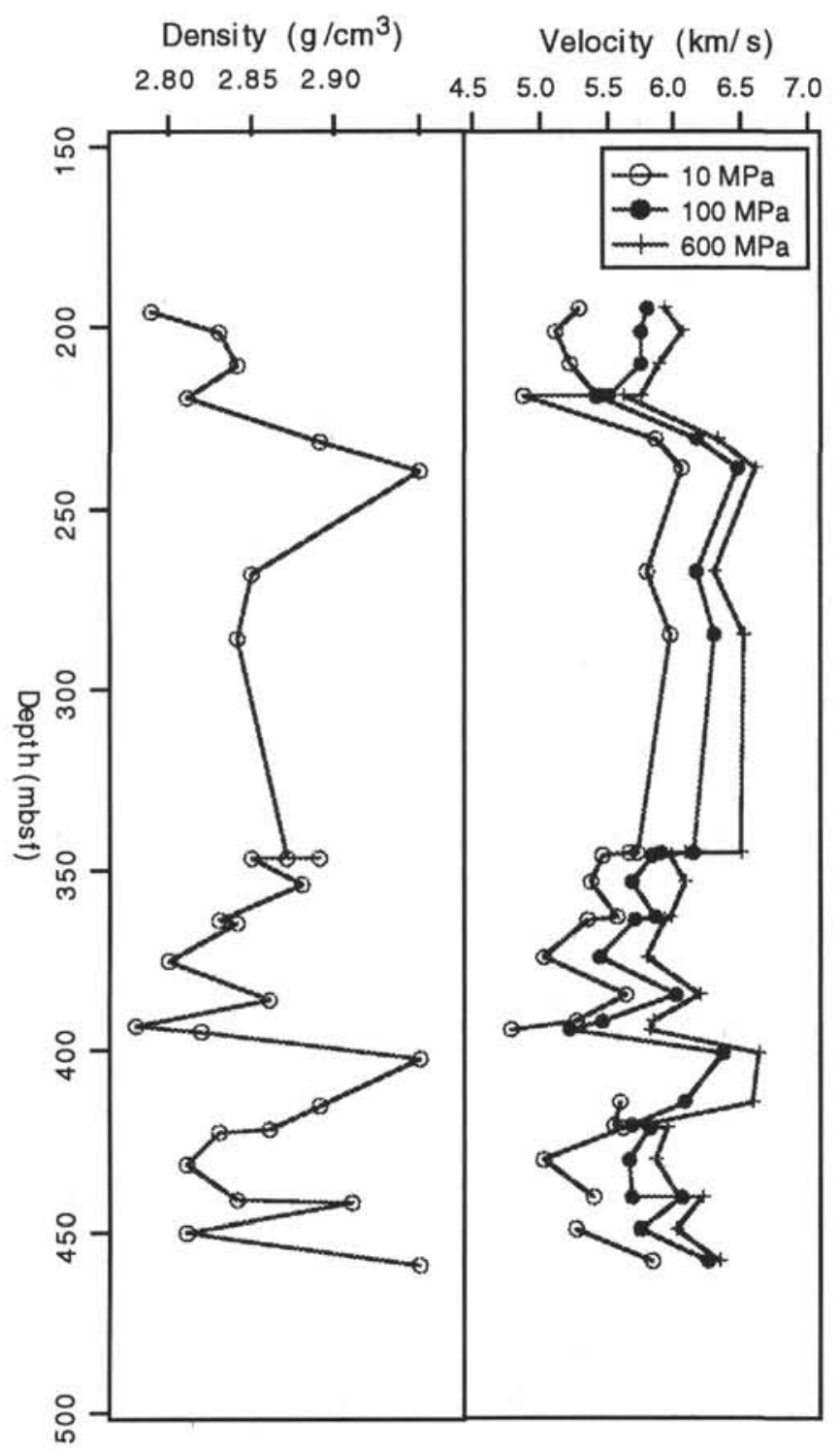

Figure 5. Density and compressional-wave velocity of laboratory samples from Hole 896A. Velocities are shown at three different confining pressures.

ous rocks. Image analysis has allowed us qualitatively to understand better the behavior of individual samples in velocity-porosity space, as well as to see changes occurring in relative abundance of mineralogy, pore space, and alteration with depth in Hole 896A. The data, both physical properties and image observations, point to the fact that there can be no simple relationship between such things as velocity and density (or porosity) in the oceanic crust, even within a group of samples from a single hole. Differences of $5 \%$ or more in density are found for samples with the same velocity. The difference approaches $10 \%$ when data from Hole 504B are added to the Hole 896A data. Clearly we need a better understanding of the effects of alteration and pore filling upon basalt physical properties.

\section{ACKNOWLEDGMENTS}

This work was supported by grants from JOI-USSAC and the Office of Naval Research. Charles Kerton ably assisted in sample preparation and image collection in Hawaii. The program NIH IMAGE, 
used for image analysis, was obtained from the National Institutes of Health.

\section{REFERENCES}

Berryman, J.G., 1985. Measurement of spatial correlation functions using image processing techniques. J. Appl. Phys., 57:2374-2384.

Birch, F., 1960. The velocity of compressional waves in rocks to 10 kilobars, 1. J. Geophys. Res., 65:1083-1102.

Caruso, L., and Simmons, G., 1984. Geological applications of backscattered electron imaging. In Proc. Electron Micros. Geol.: Tempe (Univ. Ariz. Press), 27-83.

Christensen, N.I., and Salisbury, M.H., 1975. Structure and constitution of the lower oceanic crust. Rev. Geophys. Space Phys., 13:57-86.

Ehrlich, R., 1984. A strong transfer function links thin section data to reservoir physics. AAPG Bull., 68:473. (Abstract)

Ehrlich, R., Crabtree, S.J., Horkowitz, K.O., and Horkowitz, J.P., 1991. Petrography and reservoir physics, I. Objective classification of reservoir porosity. AAPG Bull., 75:1547-1562.

Hadley, K., 1976. Comparison of calculated and observed crack densities and seismic velocities in Westerly Granite. J. Geophys. Res., 81:34843494.

Hobart, M.A., Langseth, M.G., and Anderson, R.N., 1985. A geothermal and geophysical survey on the south flank of the Costa Rica Rift: Sites 504 and 505. In Anderson, R.N., Honnorez, J., Becker, K., et al., Init. Repts. DSDP, 83: Washington (U.S. Govt. Printing Office), 379-404.

Jacobson, R.S., 1992. The impact of crustal evolution on changes of the seismic properties of the uppermost ocean crust. Rev. Geophys., 30:23-42.

Moos, D., and Marion, D., 1994. Morphology of extrusive basalts and its relationship to seismic velocities in the shallow ocean crust. J. Geophys. Res., 99:2985-2994.

Mottl, M.J., 1989. Hydrothermal convection, reaction, and diffusion in sediments on the Costa Rica Rift flank: pore-water evidence from ODP Sites 677 and 678. In Becker, K., Sakai, H., et al., Proc. ODP, Sci. Results, 111: College Station, TX (Ocean Drilling Program), 195-213.
Pye, K., and Krinsley, D.H., 1984. Petrographic examination of sedimentary rocks in the SEM using backscattered electron detectors. J. Sediment. Petrol., 54:877-888.

Raitt, R.W., 1963. The crustal rocks. In Hill, M.N. (Ed.), The Sea-Ideas and Observations on Progress in the Study of the Seas (Vol. 3): The Earth Beneath the Sea: New York (Wiley-Interscience), 85-102.

Salisbury, M.H., and Christensen, N.I., 1978. The seismic velocity structure of a traverse through the Bay of Islands ophiolite complex, Newfoundland, an exposure of oceanic crust and upper mantle. J. Geophys. Res. 83:805-817.

Salisbury, M.H., Christensen, N.I., Becker, K., and Moos, D., 1985. The velocity structure of Layer 2 at Deep Sea Drilling Project Site 504 from logging and laboratory experiments. In Anderson, R.N., Honnorez, J., Becker, K., et al., Init. Repts. DSDP, 83: Washington (U.S. Govt. Printing Office), 529-539.

Wilkens, R., Schultz, D., and Carlson, R., 1988. Relationship of resistivity, velocity, and porosity for basalts from downhole well-logging measurements in Hole 418A. In Salisbury, M.H., Scott, J.H., et al., Proc. ODP Sci. Results, 102: College Station, TX (Ocean Drilling Program), 69-75.

Wilkens, R.H., Christensen, N.I., and Slater, L., 1983. High-pressure seismic studies of Leg 69 and 70 basalts. In Cann, J.R., Langseth, M.G., Honnorez, J., Von Herzen, R.P., White, S.M., et al., Init. Repts. DSDP, 69: Washington (U.S. Govt. Printing Office), 683-686.

Wilkens, R.H., Fryer, G.J., and Karsten, J., 1991. Evolution of porosity and seismic structure of upper oceanic crust: importance of aspect ratios. $J$. Geophys. Res., 96:17891-17995.

Wilkens, R.H., Simmons, G., and Caruso, L., 1984. The ratio $V_{p} / V_{s}$ as a discriminant of composition for siliceous limestones. Geophysics, 49:18501860 .

Date of initial receipt:15 August 1994

Date of acceptance: 13 March 1995

Ms 148SR-139

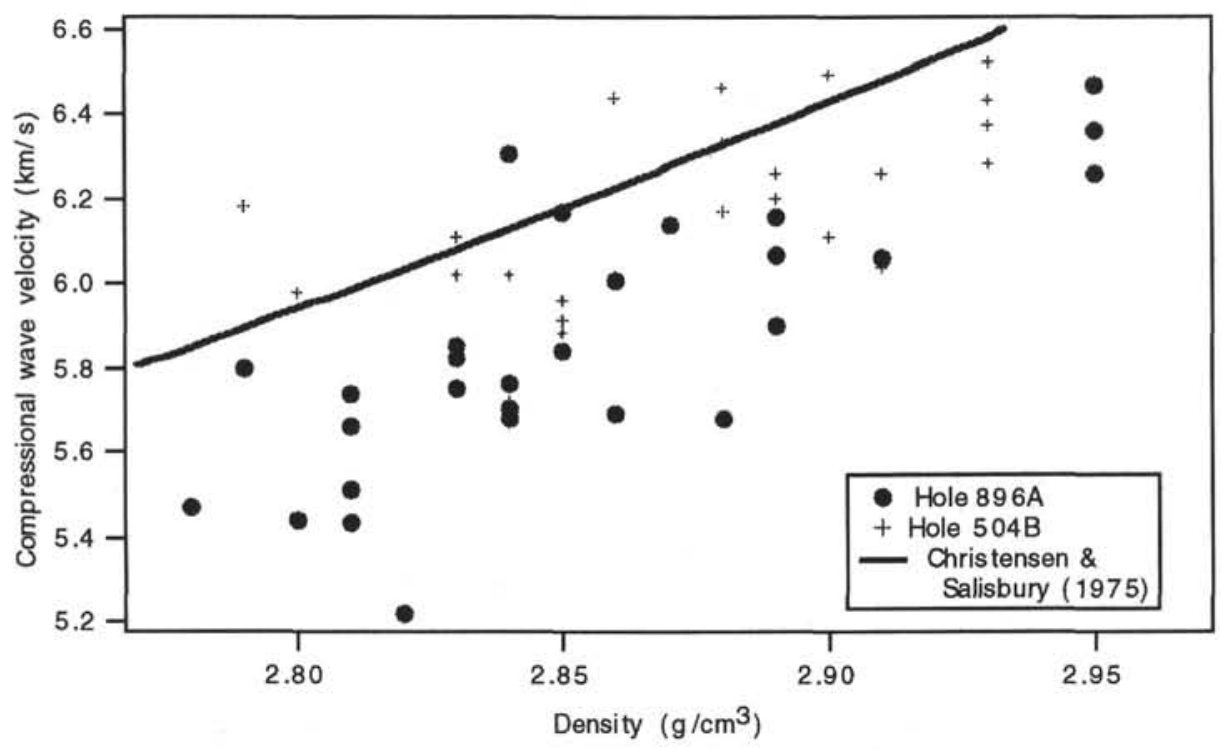

Figure 6. Compressional-wave velocity at $100 \mathrm{MPa}$ vs. wet-bulk density. Hole 504B laboratory samples are generally faster than Hole $896 \mathrm{~A}$ samples for a similar density. 


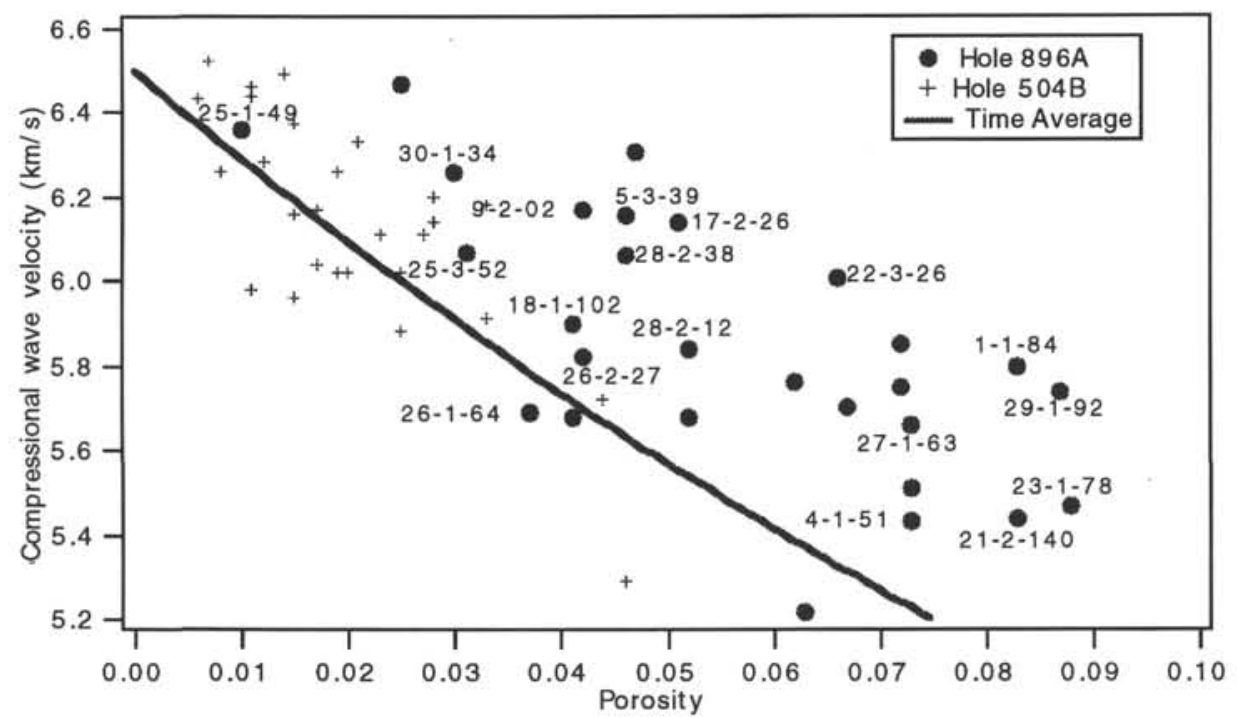

Figure 7. Porosity vs. compressional-wave velocity at $100 \mathrm{MPa}$ confining pressure. Labels are samples examined with SEM and listed in Table 2. Hole 896A samples have generally greater porosity than those of Hole 504B.

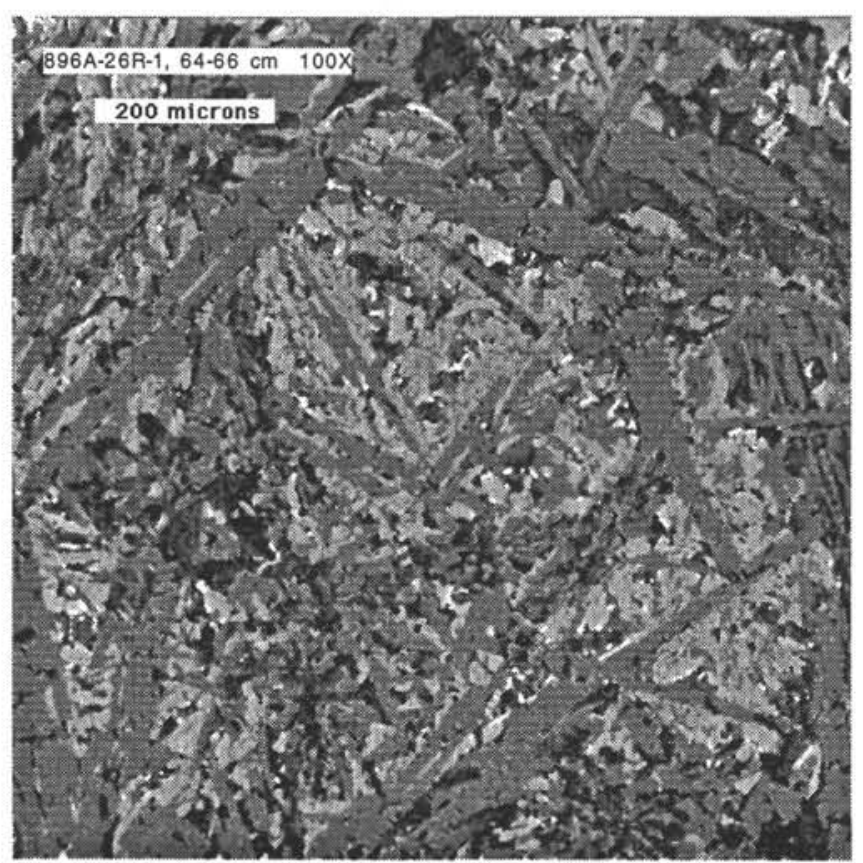

Figure 8. Notice that the pore spaces are filled with alteration minerals. Very little open pore space is in evidence.

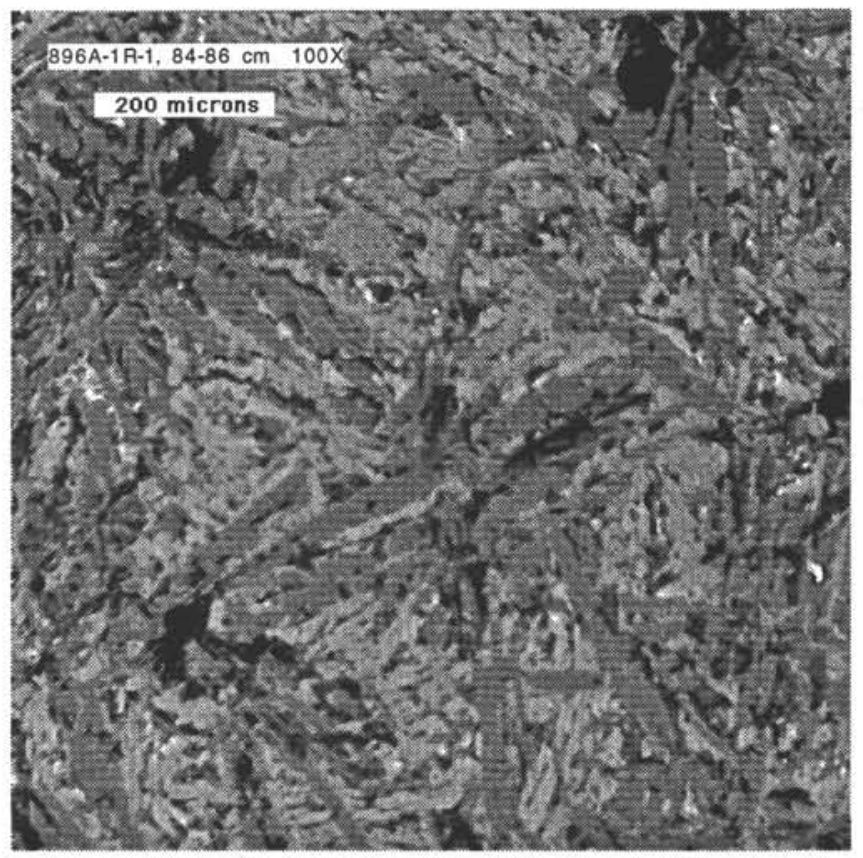

Figure 9. The pore spaces in this sample are free of alteration products. 


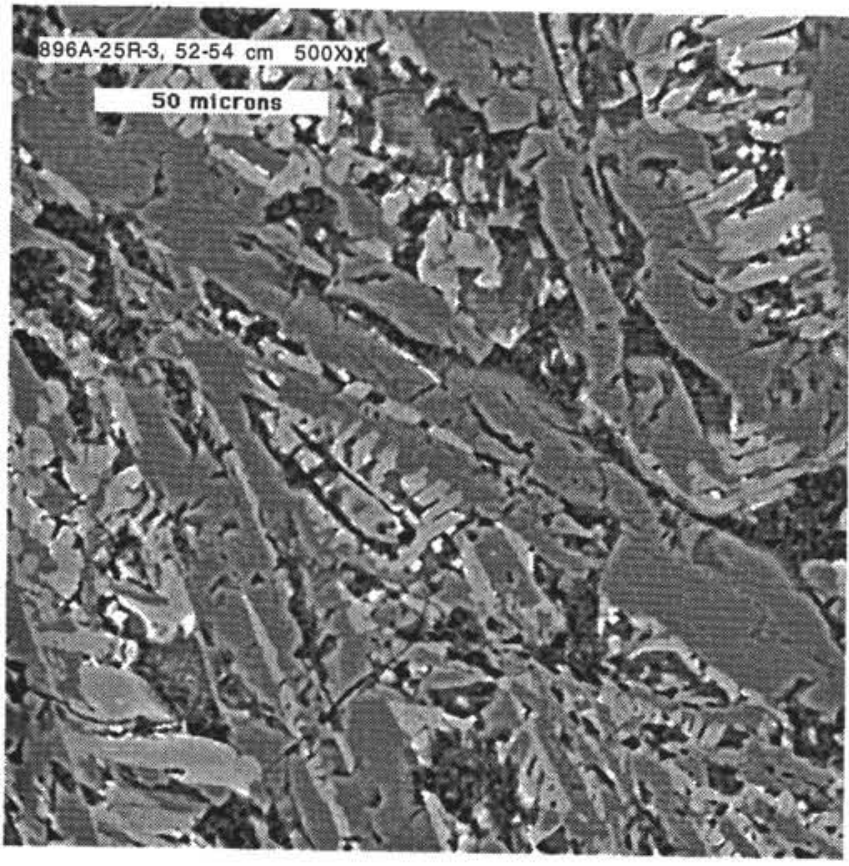

Figure 10. This sample exhibits relatively low porosity among others of similar velocity. Pore spaces are filled with alteration minerals.

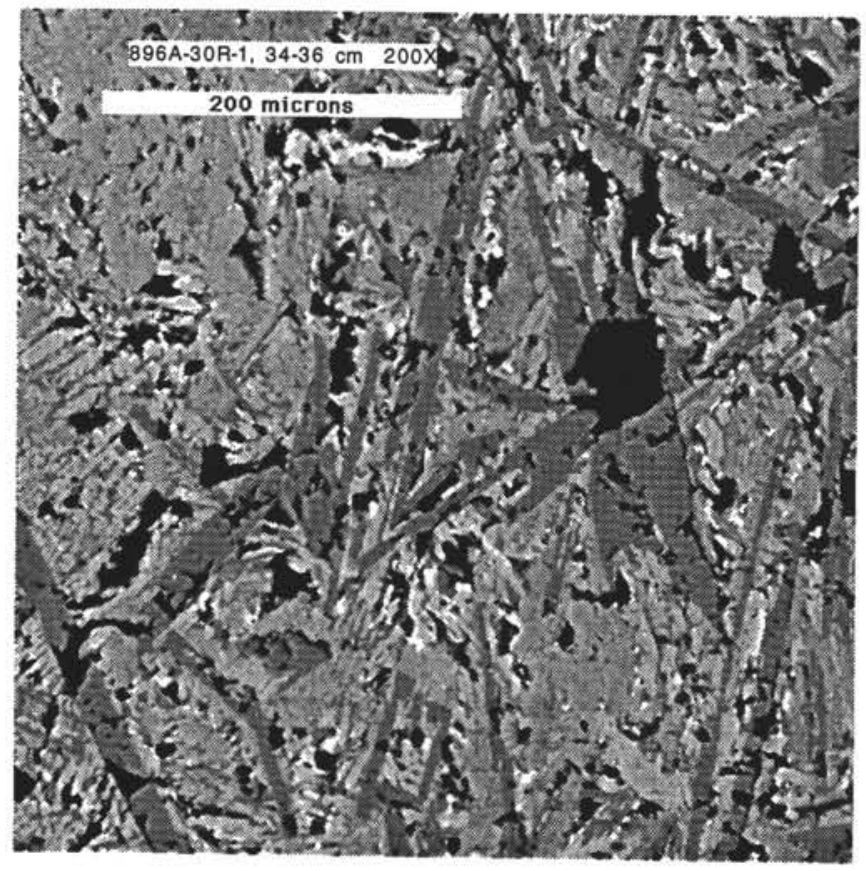

Figure 12. Clean pores in this sample suggest relatively high velocity for its porosity.

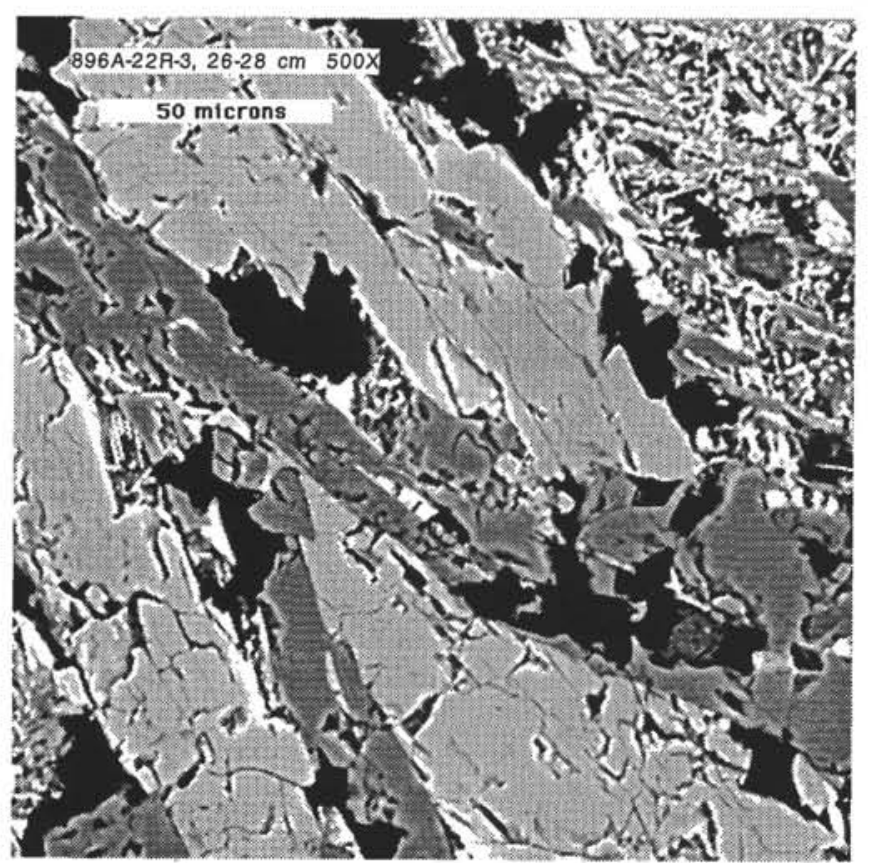

Figure 11. Sample with very little alteration of pore space.

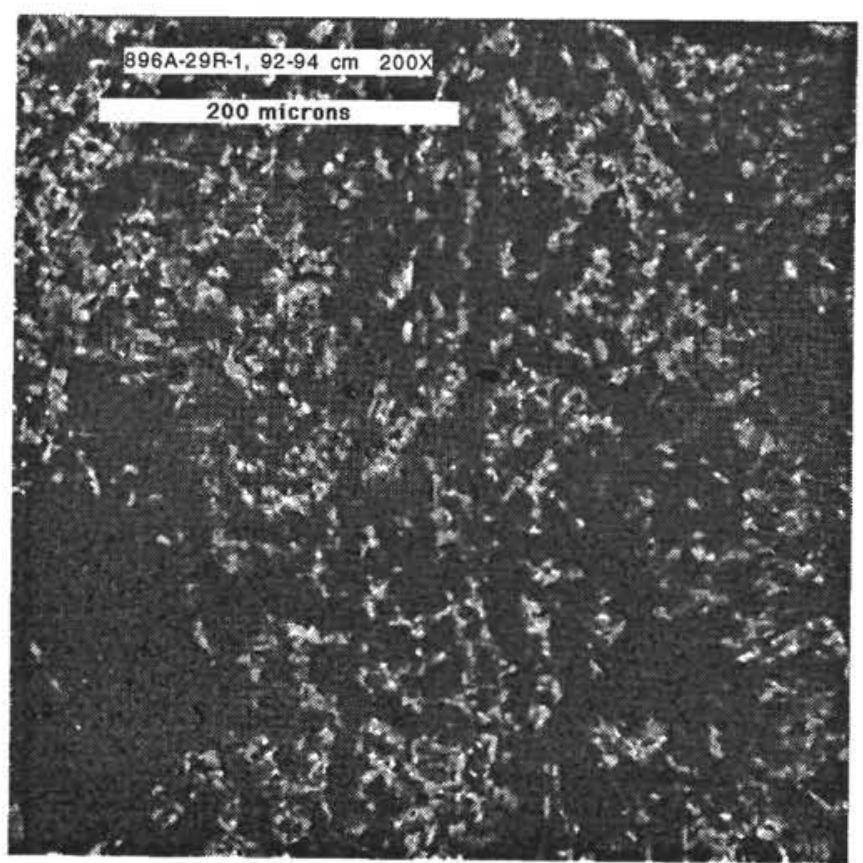

Figure 13. Sample with almost total alteration. Note the lack of microcracks. 


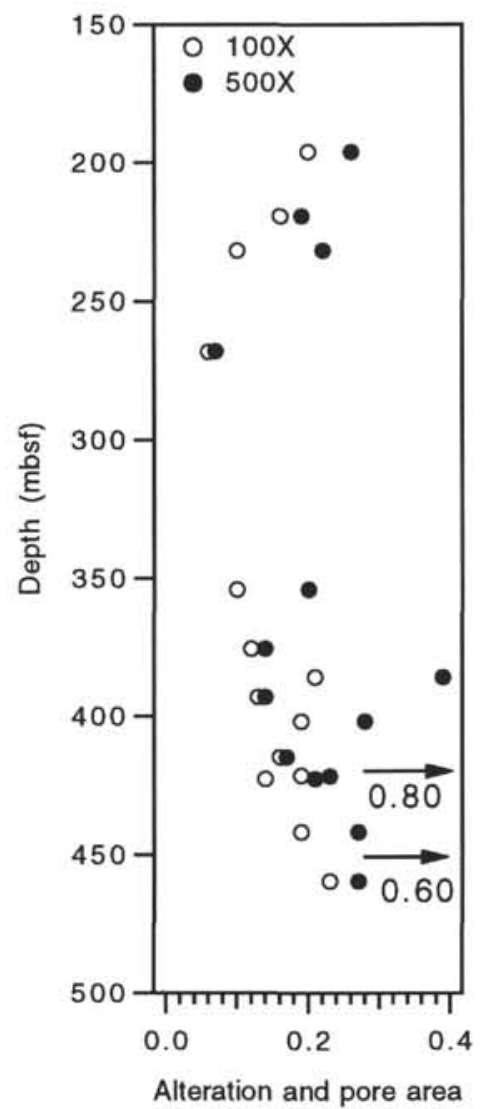

Figure 14. Alteration and pore-space area vs. depth. Two of the deeper samples were almost totally altered. 